SAARC J. Agri., 12(1), 26-32(2014)

\title{
EVALUATION OF INTERCROPPING SYSTEMS IN SPRING MAIZE WITH SUNFLOWER AND URDBEAN IN NORTH WESTERN PLAIN OF INDIA
}

\author{
A. Bhatnagar ${ }^{*}$ and M. S. Pal \\ Department of Agronomy, G. B. Pant University of Agriculture and \\ Technology Pantnagar-263145, Uttarakhand, India
}

\begin{abstract}
A field experiment was conducted for two years (2007 and 2008) at the G. B. Pant University of Agriculture and Technology, Pantnagar to study the productivity, biological efficiency and economics of intercropping in spring maize (Zea mays L.) with sunflower (Helianthus annuus L.) and urdbean (Vigna mungo L.) under different spatial arrangements. The experiment consisting of ten treatments i.e. three sole crops (maize, sunflower and urdbean), six replacement intercropping system of maize with each sunflower and urdbean in row ratios of $1: 1,2: 1$ and $3: 1$ and one additive intercropping system of maize with urdbean in row ratios of $1+1$ was laid out in randomized block design with three replications. The intercropping system of maize with urdbean in row ratio $(1+1)$ was found beneficial over sole cropping of maize and gave the maximum maize-equivalent yield $\left(5847 \mathrm{~kg} \mathrm{ha}^{-1}\right)$, landequivalent ratio (1.36) and net return (Rs.13420 $\mathrm{ha}^{-1}$ ). Intercropping of maize in replacement arrangement was not productive and advantageous than respective sole crops.
\end{abstract}

Key words: Intercropping, Maize, Productivity, Sunflower, Urdbean

\section{INTRODUCTION}

Maize can be grown in spring season (February - May) successfully in northern parts of India after the harvest of sugarcane, vegetable pea, toria, potato etc. (Kaur et al., 2010). Fewer incidences of insect pests, poor growth of weeds, proper availability of solar radiation and low relative humidity during this season make this crop more productive. Another advantage associated with

*Corresponding author email: bhatnagaramit75@gmail.com

Received: 12.06 .2013 
the crop is the availability of green fodder of maize in lean months after the harvest. The productivity of the system can possibly be augmented by intercropping with suitable crop. Growing of sunflower or urdbean in association with maize may be a feasible and viable agronomic practice for increasing the production of oilseed and pulses.

This system may also be helpful in improving resource use efficiency (Solanki et al., 2011). Inclusion of grain legumes and oilseeds in cereal/cereal cropping systems as intercrop or substitute crop has been found to augment the productivity and profitability (Yadav et al., 1998 and Pandey et al,, 2003) Plant population and spatial arrangement in intercropping have important effects on the balance of competition between component crops and their productivity (Seran and Brintha, 2009). The association of intercrop with main crop either in additive or replacement series must be biologically sustainable and economically viable (Dabbagh et al., 2011). Hence the present experiment was undertaken to study intercropping interaction between component crops and find out the possibility of increasing production of maize through spatial arrangement of intercrop.

\section{MATERIALS AND METHODS}

Field experiments were conducted during spring season of 2007 and 2008 at the Norman E. Borlaug Crop Research Centre of G. B. Pant University of Agriculture and Technology, Pantnagar $\left(29^{\circ} \mathrm{N}\right.$ and $79.5^{\circ} \mathrm{E}, 243.8 \mathrm{~m}$ above $\mathrm{msl}$ ). The soil was sandy loam in texture, neutral in reaction $\left(\mathrm{P}^{\mathrm{H}} 7.4\right)$, medium in organic carbon $(0.68 \%)$, low in available nitrogen $\left(236 \mathrm{~kg} \mathrm{ha}^{-1}\right)$, medium in available phosphorus $\left(19 \mathrm{~kg} \mathrm{ha}^{-1}\right)$ and potassium $\left(156 \mathrm{~kg} \mathrm{ha}^{-1}\right)$.The treatments were consisted of three sole crops of maize (var. Gaurav), sunflower (var.PAC 3776) and urdbean (var. Pant U 19), six replacement intercropping system of maize with each sunflower and urdbean in row ratios of $1: 1,2: 1$ and $3: 1$ and one additive intercropping system of maize with urdbean in row ratios of $1+1$ i.e. one row of urdbean between two rows of maize. The experiment consisting of ten treatments was laid out in randomized block design with three replications. The row spacing for each crop was $45 \mathrm{~cm}$. The crops were sown on 23 and 21 February in 2007 and 2008, respectively. Maize and sunflower harvested on 1 June in both the years. Urdbean was harvested on 24 May in 2007 and 20 May in 2008. The main and intercrops were grown with their full agronomic practices. The nutrients in sole stand of maize and sunflower were applied as 120:30:33 and in urdbean 15:18:33 kg N, P and $\mathrm{K} \mathrm{ha}{ }^{-1}$ and in intercrops as per their row ratios. The crops in both the years were irrigated four times except urdbean thrice. The treatment effects during both the years were more or less similar and hence 2 years data were averaged and statistically analyzed. Different competition indices were calculated as per 
described by Wiley, 1979. For comparison between treatments, the yields of all intercrops were converted in to maize equivalent yield on the basis of local market price of crops. Maize equivalent yield (MEY) was calculated by using the following formula:

MEY $=$ Maize grain yield $\left(\mathrm{kg} \mathrm{ha}^{-1}\right)+$ Yield $\left(\mathrm{kg} \mathrm{ha}^{-1}\right)$ of intercrop $\times$ price of intercrop/ price of maize.

The economics of treatments were computed on the basis of prevailing market rates of the different commodities.

\section{RESULTS AND DISCUSSION}

\section{Productivity of main crop and intercrops}

Sole crop of maize showed higher grain yield over its respective intercropped stand in association with sunflower (Table 1). The yield of intercrops were drastically reduced except higher in maize+ urdbean because of low plant population of intercrops in replacement planting. The reduction in yield of maize intercropped with sunflower varied with spatial arrangement which was $63.6,72.2$ and $77.8 \%$ of sole crop in $1: 1,2: 1$ and $3: 1$ row arrangement, respectively. The depressing effect of sunflower on maize under 3:1 row ratio was minimized due to more number of rows of maize. Sole crop of maize recorded lower yield over its respective intercropped stand when grown in association with urdbean either in additive or replacement series. Grain yield of maize in association with urdbean in additive row arrangement was $108 \%$ of sole crop whereas remained about $103 \%$ in all row combination of replacement series. It may be due to regular and timely availability of nitrogen fixed by associated legume plants (Singh et al., 2000). The lower yield levels of maize with sunflower than those of urdbean might be attributed to sever competition offered by sunflower. Sole crops of sunflower and urdbean recorded higher seed yield over their respective intercropped stands. Seed yield of sunflower and urdbean decreased due to intercropping with maize irrespective of row arrangement. The yield of sunflower in all intercropping row combinations was about $89 \%$ of sole crop over their respective intercropped stands. However, in case of urdbean magnitude of reduction varied with spatial arrangement ranging from $27.8 \%(1+1$ additive rows) to $70.5 \%$ (3:1 rows). Such reduction in yield of sunflower and urdbean might be due to shading and competition effect by maize plants. The highest reduction in yield of urdbean in 1+1 additive series was due to intense shading effect owing to higher population of maize.

All the intercropping systems except maize + urdbean in additive rows showed inferiority to sole cropping of maize, as evident by maize-equivalent yield. The maximum maize equivalent yield $\left(5847 \mathrm{~kg} \mathrm{ha}^{-1}\right)$ was recorded with 
maize + urdbean in additive rows which was $25.3,15.7$ and $30.3 \%$ higher than sole crop of maize, sunflower and urdbean, respectively. Higher maize equivalent yield in additive arrangement was due to additional bonus yield of intercrop and balanced competition between component crop species. Sole sunflower had more maize-equivalent yield compared with sole crop of maize and urdbean owing to higher price. These results agreed with the findings of Padhi, 2001.

\section{Intercropping interactions}

Intercropping system of maize with sunflower and urdbean resulted in land-equivalent ratio (LER) lesser than 1 except with urdbean in additive combination, indicating intercropping in replacement series in not advantageous (Table 2). The mean LER in 2 years ranged from 0.77 to 1.36, indicating that intercropping system had a greater impact on the productivity of the system. Intercropping system of maize with sunflower and urdbean in 1:1 row proportion showed the minimum biological efficiency $(0.77$ and 0.85 , respectively) of the system whereas the additive spatial arrangement of urdbean had the maximum value (1.36). The yield advantage due to intercropping in additive row combination may possibly be attributed to the combined effect of better utilization of growth factors. The association of maize with sunflower and urdbean in replacement series irrespective of row ratio gave lower LER, indicating insufficient systems. The companion crop of sunflower appeared more competitive than maize giving higher values for competitive ratio. The lower values of competitive ratio of urdbean suggested that maize is more competitive than urdbean. It is further evident from aggressivity factor where sunflower was aggressive with maize and maize with urdbean. The relative crowding coefficient values of maize were always less than 1 with sunflower and greater than 1 with urdbean, indicating that maize gave lower yield than expected with sunflower and higher yield with urdbean. But product of crowding coefficient was lower than unity, indicating no yield advantage in intercropping of maize under replacement row combination with sunflower or urdbean. It indicated that intercropping of maize with sunflower or urdbean is not biologically suitable in replacement row system.

\section{Net return}

Intercropping of maize in replacement series either with sunflower or urdbean at different row ratios did not give higher net returns than sole crop of maize, sunflower and urdbean and was minimum with sunflower in 1:1 ratio (Table 2). The association of maize with urdbean in $1+1$ additive series gave the maximum net return (Rs. $28610 \mathrm{ha}^{-1}$ ) which was 47, 39 and 59\% more than sole crop of maize, sunflower and urdbean, respectively. 
A. Bhatnagar and M. S. Pal

\section{CONCLUSION}

It can be concluded that intercropping of maize with sunflower or urdbean in replacement arrangement is not biologically suitable and advantageous in spring season but maize with urdbean in $1+1$ additive series is more productive and economically remunerative.

\section{REFERENCES}

Dabbagh Mohammadi Nassab A, Amon, T. and Kaul, H.P.2011. Competition and yield in intercrops of maize and sunflower for biogas. Industrial Crops and Products, 34(1):1203-1211

Kaur R., Saxena V.K. and Malhi, N.S. 2010. Combining ability for heat tolerance traits in spring maize (Zea mays L.) Maydica, 55: 195-199

Padhi, A.K. 2001. Effect of vegetable intercropping on productivity, economics and energitics of maize (Zea mays). Indian Journal of Agronomy, 46(2): 204-210

Pandey, I.B., Bharti, V. and Mishra, S.S. 2003. Effect of maize (Zea mays)based intercropping systems on maize yield and associated weeds under rainfed condition. Indian Journal of Agronomy, 48(1): 30-33

Seran, T.H. and Brintha, I. 2009. Study on biological and economic efficiency of Radish (Raphanus sativus L.) intercropped with vegetable amaranthus (Amaranthus tricolor L.). The Open Horticulture Journal, 2: $17-21$

Singh, D.P., Rana, N.S. and Singh, R.P. 2000. Growth and yield of winter maize (Zea mays) as influenced by intercrops and nitrogen application. Indian Journal of Agronomy, 45(3): 515-519

Solanki, N.S., Singh D. and Sumeriya H.K. 2011. Resources utilization in maize (Zea mays)- based intercropping system under rainfed condition. Indian Journal of Agricultural Sciences, 81(6): 511-15

Wiley, R.W. 1979. Intercropping - its importance and research needs. Part I. Field Crops Abstracts, 32(1): 1-10

Yadav, R.L., Dwivedi, B.S., Gangwar, K.S. and Prasad, K. 1998. Overview and prospects for enhancing residual benefits of legumes in rice and wheat cropping systems in India. p. 207-225. In: Kumar et al. (ed.), Residual Effect of legumes in Rice and Wheat Cropping Systems of the Indo-Gangetic Plains, Oxford \& IBH Publication, New Delhi. 
Table1. Yield of sole and intercrops as affected by intercropping systems (mean of 2 years)

\begin{tabular}{|c|c|c|c|c|}
\hline Treatment & $\begin{array}{l}\text { Maize grain } \\
\text { yield } \\
\left(\mathrm{kg} \mathrm{ha}^{-1}\right)\end{array}$ & $\begin{array}{c}\text { Sunflower seed } \\
\text { yield } \\
\left(\mathrm{kg} \mathrm{ha}^{-1}\right)\end{array}$ & $\begin{array}{c}\text { Urdbean seed } \\
\text { yield } \\
\left(\mathrm{kg} \mathrm{ha}^{-1}\right)\end{array}$ & $\begin{array}{c}\text { Maize equivalent } \\
\text { yield } \\
\left(\mathrm{kg} \mathrm{ha}^{-1}\right)\end{array}$ \\
\hline \multicolumn{5}{|c|}{ Sole Cropping } \\
\hline Maize & 4365 & - & - & 4365 \\
\hline Sunflower & - & 2073 & - & 4929 \\
\hline Urdbean & - & - & 1397 & 4078 \\
\hline \multicolumn{5}{|c|}{ Intercropping } \\
\hline \multicolumn{5}{|c|}{ Maize: Sunflower } \\
\hline $1: 1$ & 1387 & 921 & - & 3573 \\
\hline $2: 1$ & 2096 & 612 & - & 3552 \\
\hline $3: 1$ & 2540 & 459 & - & 3631 \\
\hline \multicolumn{5}{|c|}{ Maize: Urdbean } \\
\hline $1+1$ additive & 4718 & & 387 & 5847 \\
\hline $1: 1$ & 2259 & - & 464 & 3613 \\
\hline $2: 1$ & 2983 & - & 330 & 3946 \\
\hline $3: 1$ & 3355 & - & 246 & 4072 \\
\hline $\mathrm{SEm} \pm$ & 86 & 32 & 20 & 103 \\
\hline $\mathrm{CD}(\mathrm{P}=0.05)$ & 260 & 111 & 63 & 306 \\
\hline
\end{tabular}

Table 2. Intercropping interactions and net return of maize, sunflower and urdbean intercropping systems (mean of 2 years)

\begin{tabular}{|l|l|l|l|l|l|l|l|l|}
\hline Treatment & LER & CRm & CRi & Am & Km & Ki & K & $\begin{array}{l}\text { Net return } \\
\left(\mathrm{Rs} \mathrm{ha}^{-1}\right)\end{array}$ \\
\hline Sole cropping \\
\hline Maize & 1.00 & & & & & & & 19509 \\
\hline Sunflower & 1.00 & & & & & & & 20527 \\
\hline Urdbean & 1.00 & & & & & & & 17995 \\
\hline Intercropping \\
\hline Maize: Sunflower \\
\hline $1: 1$ & 0.77 & 0.72 & 1.42 & -0.26 & 0.47 & 0.82 & 0.38 & 12376 \\
\hline $2: 1$ & 0.78 & 0.82 & 1.24 & -0.17 & 0.47 & 0.86 & 0.41 & 12642 \\
\hline $3: 1$ & 0.81 & 0.89 & 1.17 & -0.12 & 0.48 & 0.87 & 0.42 & 13420 \\
\hline
\end{tabular}




\begin{tabular}{|l|l|l|l|l|l|l|l|l|}
\hline Maize: Urdbean & \multicolumn{10}{|l|}{} & \\
\hline $1+1$ additive & 1.36 & - & - & - & - & - & - & 28610 \\
\hline $1: 1$ & 0.85 & 1.57 & 0.64 & 0.37 & 1.10 & 0.50 & 0.55 & 14318 \\
\hline $2: 1$ & 0.89 & 1.45 & 0.70 & 0.31 & 1.12 & 0.62 & 0.70 & 16622 \\
\hline $3: 1$ & 0.94 & 1.47 & 0.69 & 0.32 & 1.12 & 0.64 & 0.71 & 17527 \\
\hline SEm \pm & 0.02 & 0.05 & 0.06 & 0.04 & 0.08 & 0.05 & 0.05 & 708 \\
\hline $\mathrm{CD}(\mathrm{P}=0.05)$ & 0.06 & 0.17 & 0.19 & 0.13 & 0.24 & 0.14 & 0.16 & 2103 \\
\hline
\end{tabular}

$\mathrm{LER}=$ land equivalent ratio; $\mathrm{CRm}$ and $\mathrm{Cri}=$ competitive ratio of maize on intercrops and intercrops on maize; $A m=$ aggresivity of maize; $\mathrm{Km}$ and $\mathrm{Ki}=$ crowding coefficient of maize on intercrops and of intercrops on maize; $\mathrm{K}=$ product of crowding coefficient.

In 2007 , price of maize grain= Rs. $6 \mathrm{~kg}^{-1}$, sunflower seed= Rs. $16.5 \mathrm{~kg}^{-1}$, urdbean seed= Rs. $17 \mathrm{~kg}^{-1}$

In 2008 , price of maize grain= Rs. $8.4 \mathrm{~kg}^{-1}$, sunflower seed= Rs. $16.5 \mathrm{~kg}^{-1}$, urdbean seed= Rs. $25.2 \mathrm{~kg}^{-1}$ 